\title{
Neurogenic Perspective on Vascular Endothelial Growth Factor: Review of the Literature
}

Romed Meirer, M.D.,' Raffi Gurunluoglu, M.D.,' and Maria Siemionow, M.D., Ph.D.1

The publisher regrets an error in the listing of degrees in the above article in the Journal of Reconstructive Microsurgery, volume 17, number 8, p. 625. Dr. Raffi Gurunluoglu's degree should have been listed as M.D., not M.D., Ph.D.

Journal of Reconstructive Microsurgery, Volume 17, Number 8, 2001. Address for correspondence and reprint requests: Maria Siemionow, M.D., Ph.D., Cleveland Clinic Foundation, Department of Plastic and Reconstructive Surgery, A60, 9500 Euclid Avenue, Cleveland, OH 44195. ${ }^{1}$ Microsurgery Laboratory, Department of Plastic and Reconstructive Surgery, Cleveland Clinic Foundation, Cleveland, OH. Copyright (C) 2003 by Thieme Medical Publishers, Inc., 333 Seventh Avenue, New York, NY 10001, USA. Tel: +1(212) 584-4662. 1526-8004,p;2003,19,03, 207,208,ftx,en;jrm00916x. 
